\title{
Metabolic engineering in woody plants: challenges, advances, and opportunities
}

\author{
Shu Yu' ${ }^{1}$, Cody S. Bekkering ${ }^{1}$, Li Tian ${ }^{1 凶}$ \\ 1 Department of Plant Sciences, Mail Stop 3, University of California, Davis, CA 95616, USA
}

Received: 1 April 2021 / Accepted: 6 June 2021 / Published online: 23 June 2021

\begin{abstract}
Woody plant species represent an invaluable reserve of biochemical diversity to which metabolic engineering can be applied to satisfy the need for commodity and specialty chemicals, pharmaceuticals, and renewable energy. Woody plants are particularly promising for this application due to their low input needs, high biomass, and immeasurable ecosystem services. However, existing challenges have hindered their widespread adoption in metabolic engineering efforts, such as long generation times, large and highly heterozygous genomes, and difficulties in transformation and regeneration. Recent advances in omics approaches, systems biology modeling, and plant transformation and regeneration methods provide effective approaches in overcoming these outstanding challenges. Promises brought by developments in this space are steadily opening the door to widespread metabolic engineering of woody plants to meet the global need for a wide range of sustainably sourced chemicals and materials.
\end{abstract}

Keywords Woody plant, Metabolic engineering, Bioeconomy, Sustainability

\section{INTRODUCTION}

Woody plants are resilient perennials defined by their characteristic woody stems and large root systems. Woody plants are a highly diverse group that is polyphyletic in origin and have both flowering and nonflowering members. Many species of woody plants have evolved since their origins around 380 million years ago, and they have since come to dominate various landscapes around the globe (Wilson et al. 2017). In contrast to herbaceous plants that can employ the strategy of escaping and avoiding stresses by dispersing their seeds (Chelli-Chaabouni 2014; Sade et al. 2018), perennial woody plants must tolerate stresses in the areas they occupy. Woody plants invest a large amount of energy in vegetative growth (e.g. producing wood) and have well-developed xylem, phloem, and root

Shu Yu and Cody S. Bekkering contributed equally.

$\bowtie$ Correspondence: ltian@ucdavis.edu (L. Tian) system that enable them to survive diverse environments and stress conditions. In this regard, some monocot species such as palm, though lacking secondary growth characteristics of true wood, have substantial metabolic investment in vegetative growth that affords them resilience comparable to true woody plants.

Approximately $80 \%$ of the biomass on Earth is stored in forests comprised of diverse woody plant flora. This immense genetic diversity remaining in woody plants serves as a precious deposit of untapped metabolic pathways that provides raw materials for metabolic engineering. The value and novelty of woody plant metabolism are paralleled in scale by their immense size and growth rate, raising promise for their use as a sustainable platform for metabolic engineering (Fig. 1). Because of the large biomass available from woody plants after establishment, high yield of desirable bioproducts can be achieved-yields that can be further expanded in some systems through short rotation planting or coppicing schemes (Ragauskas et al. 2006). 


\section{Metabolic Engineering of Woody Plants}
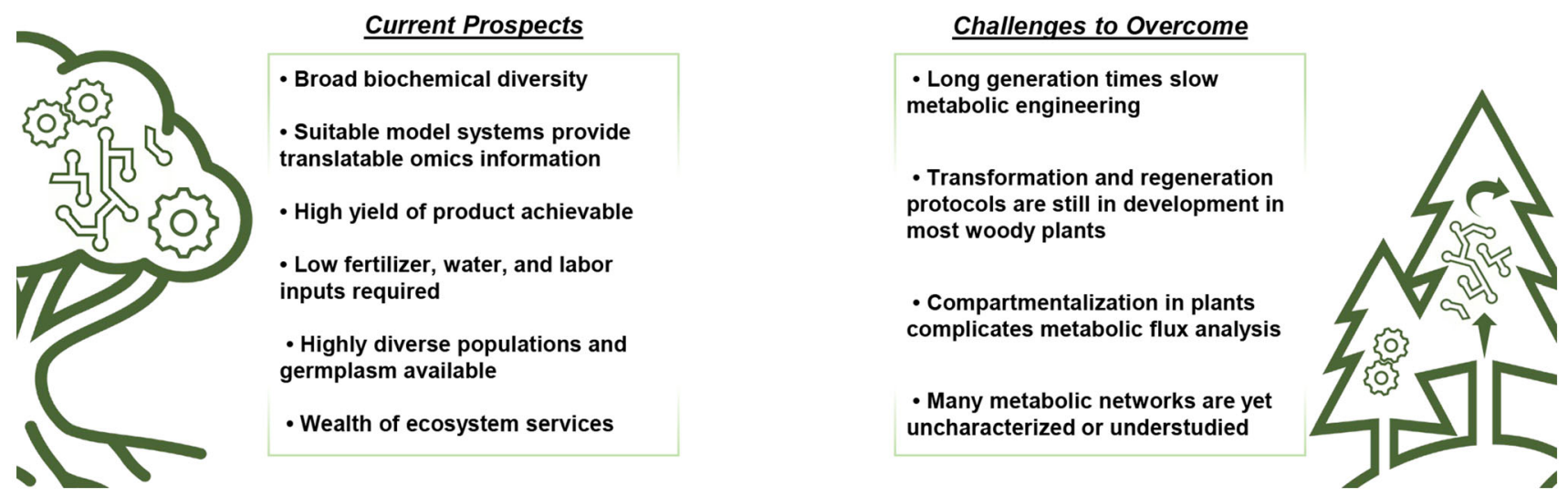

Fig. 1 Prospects and current challenges of leveraging woody plants in metabolic engineering

Perennial woody plant cultivation can operate with less inputs, such as fertilizer, water, and labor, and can also adapt to different environments including land too marginal for conventional food crops, lowering their impact on the global food system. Woody plants are favored for biofuel production from lignocellulosic biomass as it is not derived from food crops, also lowering their strain on the global food system (Bryant et al. 2020; Choi et al. 2020). Moreover, the ecological benefits of woody plants are also considerable-contributing habitat, shade, erosion protection, and soil carbon sequestration. This suite of advantages makes woody plants a sound platform for metabolic engineering in the sustainable bioeconomy of tomorrow.

Despite the broad advantages of leveraging woody plant systems for metabolic engineering, they present unique challenges also (Fig. 1). The life cycle of woody plants is often long and prohibitive to engineering approaches that require multiple generations. In addition, many valuable phytochemicals produced by woody plants are low in accumulation-with some being synthesized only in response to certain stimuli due to their function in defense (Burlacu et al. 2020; Oleszek et al. 2019). The physiological and genetic understanding of woody plant species is also generally exceeded by that of more intensively studied herbaceous plants (Burlacu et al. 2020). Finally, some woody plants are difficult to transform and regeneration rates of many woody plants following transformation remains low, adding difficulty to engineering approaches that require genetic transformation. Nonetheless, there is current progress in the study of woody plant biology that alleviates these inhibitions to metabolic engineering. In this review, we will focus on current advances in woody plant metabolic engineering that has met some of the pressing challenges to their implementation; in addition, promising trajectories will also be discussed that chart the course for woody plant metabolic engineering in the near future.

\section{GOALS AND PROGRESS OF METABOLIC ENGINEERING OF WOODY PLANTS}

\section{Improving the growth performance and disease resistance properties of woody plants}

To mitigate biotic and abiotic stresses, woody plants produce a variety of specialized metabolites that belong to many chemical classes including (but not limited to) terpenoids, alkaloids, simple phenolics, coumarins, tannins, and lignins. There have been several examples of successful metabolic engineering efforts centered on the accumulation of such compounds in woody plants (Table 1). Proanthocyanidins (PAs) are phenolic metabolites that can induce plant defense mechanisms and protect plants from pathogens (Ullah et al. 2017; Wang et al. 2017). Overexpression of a transparent testa 2 (TT2)-like transcription factor MYB115 in poplar enhanced the biosynthesis of PAs by positively regulating PA biosynthetic genes, which led to lessened disease symptoms when leaves were inoculated with the fungal pathogen Dothiorella gregaria (Wang et al. 2017). Resveratrol is a phenolic phytoalexin with protective roles for plants that is also an antioxidant associated with human health benefits. Metabolic engineering of piceid, a resveratrol glucoside, has been achieved in apple (Malus domestica) in two studies despite piceid not occurring naturally in apple (Kobayashi et al. 2000; Rühmann et al. 2006). In one example, expression of the stilbene synthase gene from grapevine (Vitis vinifera) in apple resulted in the accumulation of piceid in 
Table 1 Feasible targets for metabolic engineering within more commonly studied woody plant species

\begin{tabular}{|c|c|c|c|}
\hline Plant family & $\begin{array}{l}\text { Major metabolite classes } \\
\text { for metabolic } \\
\text { engineering }\end{array}$ & Physiological role & Engineering examples \\
\hline \multirow[t]{2}{*}{ Euphorbiaceae } & Curcins & Biotic stress resistance & Jatropha curcas: Gu et al. (2015) \\
\hline & Fatty acids/lipids & $\begin{array}{l}\text { Carbon and energy } \\
\text { reserve }\end{array}$ & Jatropha curcas: Maravi et al. (2016), Qu et al. (2012) \\
\hline \multirow[t]{3}{*}{ Myrtaceae } & Monoterpenes & Defense & Eucalyptus camaldulensis: Ohara et al. (2010) \\
\hline & Lignin & $\begin{array}{l}\text { Structural support, } \\
\text { defense }\end{array}$ & Hybrid eucalyptus: Sykes et al. (2015) \\
\hline & Glycinebetaine & Abiotic stress tolerance & Eucalyptus globulus: Matsunaga et al. (2012) \\
\hline \multirow[t]{8}{*}{ Salicaceae } & Lignin & $\begin{array}{l}\text { Structural support, } \\
\text { defense }\end{array}$ & $\begin{array}{l}\text { Hybrid poplar: Baucher et al. (1996), Coleman et al. (2008), } \\
\text { Huntley et al. (2003), Van Acker et al. (2014), Van } \\
\text { Doorsselaere et al. (1995), Voelker et al. (2011) }\end{array}$ \\
\hline & Carbohydrates & $\begin{array}{l}\text { Carbon and energy } \\
\text { reserve }\end{array}$ & $\begin{array}{l}\text { Hybrid poplar: Coleman et al. (2007), Lee et al. (2009); White } \\
\text { poplar: Park et al. (2004) }\end{array}$ \\
\hline & Proanthocyanidins & Defense & $\begin{array}{l}\text { Hybrid aspen: Mellway and Constabel (2009); Chinese white } \\
\text { poplar: Wang et al. (2017), Yuan et al. (2012) }\end{array}$ \\
\hline & Stilbenoids & Biotic stress resistance & $\begin{array}{l}\text { White poplar: Giorcelli et al. (2004); Hybrid aspen: Seppänen et al. } \\
\text { (2004) }\end{array}$ \\
\hline & Glutamine & Nitrogen assimilation & Hybrid poplar: Jing et al. (2004) \\
\hline & Glutathione & Defense & Hybrid poplar: Koprivova et al. (2002) \\
\hline & Bioplastic (PHB) & $\begin{array}{l}\text { Not natural in woody } \\
\text { plants }\end{array}$ & Hybrid poplar: Dalton et al. (2011) \\
\hline & Phenylpropenes & Attractant and defense & Hybrid aspen: Koeduka et al. (2013) \\
\hline \multirow[t]{2}{*}{ Actinidiaceae } & Carotenoids & $\begin{array}{l}\text { Photosynthesis, fruit } \\
\text { color }\end{array}$ & Kiwifruit: Kim et al. (2010) \\
\hline & Stilbenoids & Biotic stress resistance & Kiwifruit: Kobayashi et al. (2000) \\
\hline \multirow[t]{4}{*}{ Rosaceae } & Stilbenoids & Biotic stress resistance & Apple: Rühmann et al. (2006), Szankowski et al. (2003) \\
\hline & Polyamines & Abiotic stress tolerance & Common pear: Wen et al. (2008) \\
\hline & Flavonoids & Defense and coloration & Apple: Rihani et al. (2017) \\
\hline & Anthocyanins & $\begin{array}{l}\text { Abiotic stress } \\
\text { tolerance, fruit color }\end{array}$ & Apple: Espley et al. (2007) \\
\hline \multirow[t]{2}{*}{ Vitaceae } & Stilbenoids & Biotic stress resistance & Grape: Coutos-Thévenot et al. (2001), Fan et al. (2008) \\
\hline & Strigolactones & Growth regulation & Grape: Ren et al. (2020) \\
\hline Rubiaceae & Alkaloids & Defense & Coffee: Ogita et al. (2004), Ogita et al. (2003) \\
\hline Theaceae & Alkaloids & Defense & Tea tree: Mohanpuria et al. (2011a), Mohanpuria et al. (2011b) \\
\hline Arecaceae & Bioplastic (PHB) & $\begin{array}{l}\text { Not natural in woody } \\
\text { plants }\end{array}$ & African oil palm: Parveez et al. (2015) \\
\hline Pinaceae $^{\dagger}$ & Lignin & $\begin{array}{l}\text { Structural support, } \\
\text { defense }\end{array}$ & $\begin{array}{l}\text { Monterey pine: Wagner et al. (2009), Wagner et al. (2007), Wagner } \\
\text { et al. (2011) }\end{array}$ \\
\hline \multirow[t]{3}{*}{ Rutaceae } & Monoterpenes & $\begin{array}{l}\text { Abiotic stress } \\
\text { tolerance, insect } \\
\text { attraction }\end{array}$ & Sweet orange: Rodríguez et al. (2018) \\
\hline & Sesquiterpenes & Defense & Sweet orange: Alquézar et al. (2021) \\
\hline & Carotenoids & $\begin{array}{l}\text { Photosynthesis, fruit } \\
\text { color }\end{array}$ & Sweet orange: Pons et al. (2014) \\
\hline Asteraceae & Natural rubber & Defense & Guayule: Placido et al. (2019) \\
\hline Juglandaceae & Ammonium & Nitrogen assimilation & Persian walnut: Liu, (2021) \\
\hline Caricaceae & Stilbenoids & Biotic stress resistance & Papaya: Zhu et al. (2004) \\
\hline
\end{tabular}


Table 1 continued

\begin{tabular}{llll}
\hline Plant family & $\begin{array}{l}\text { Major metabolite classes } \\
\text { for metabolic } \\
\text { engineering }\end{array}$ & Physiological role & Engineering examples \\
\hline Ebenaceae & $\begin{array}{l}\text { Glycinebetaine } \\
\text { Sorbitol }\end{array}$ & $\begin{array}{l}\text { Abiotic stress tolerance } \\
\text { Abiotic stress } \\
\text { tolerance, biotic } \\
\text { stress resistance }\end{array}$ & Japanese persimmon: Gao et al. (2000) \\
& & Japanese persimmon: Gao et al. (2001) \\
\hline
\end{tabular}

Engineering successes for each target are shown

${ }^{\dagger}$ Gymnosperm

transgenic apple fruits (Rühmann et al. 2006). Although piceid has implications in phytopathology, these piceidaccumulating apple plants were not subjected to pathogen stress to test their disease resistant properties.

Engineering of volatile organic compounds (VOCs) is similarly applied to the protection of woody plants from pests and pathogens by disrupting their interactions with the host plant (Pickett and Khan 2016). In one example, orange (Citrus sinensis) was engineered to produce less limonene (major VOC in oil glands of mature orange fruit) and instead accumulate increased monoterpene alcohols that share the common biosynthetic precursor geranyl pyrophosphate with limonene, increasing resistance to fungal pathogens that would otherwise lower yields and shelf life (Rodríguez et al. 2018). Overexpressing the Arabidopsis $\beta$-caryophyllene synthase gene in sweet orange leaves caused large emissions of a VOC $\beta$-caryophyllene. As $\beta$-caryophyllene functions as a repellent of Diaphorina citri, the transgenic orange plants showed reduced attraction to $D$. citri, an insect vector of the notorious crop disease "Huanglongbing", in olfactometric behavioral assays and the choice behavioral test, demonstrating the potential of this approach for controlling Huanglongbing (Alquezar et al. 2021).

Phytohormones, despite their complex crosstalk, are also logical targets for metabolic engineering of woody plants due to their mediation of many processes including growth, stress tolerance, and phenology (Fenn and Giovannoni 2021). Auxins, gibberellins, brassinosteroids, cytokinins, jasmonic acid, salicylic acid, and ethylene can have their biosynthesis altered to change the biomass accumulation and architecture of woody plants to better suit agronomic usage or improve product quality (Dubouzet et al. 2013; Osakabe et al. 2011). Work in poplar has produced multiple successful examples-with hormone signaling being modified to produce fast growing, narrow trees amenable to usage in close stands (Mauriat and Moritz 2009; Nieminen et al. 2008). Ethylene biosynthesis, for example, has also been suppressed in apple to produce fruits with longer shelf life (Dandekar et al. 2004). However, complex crosstalk in hormone signaling can result in deleterious pleiotropic effects when hormone signaling is manipulated. Work on transgenic poplar demonstrates this, as lines overexpressing abscisic acid responsive element proteins displayed increased drought tolerance at the expense of biomass accumulation (Yu et al. 2019). Existing knowledge of hormonal signaling networks can be leveraged in woody plants to optimize growth and the value of the desired product while attempting to mitigate pleiotropic effects brought on by crosstalk. One such approach could be targeting specific transcription factors or receptors implicated in the hormone signaling rather than the hormone synthesis itself.

\section{Enhancing the nutritional quality of woody plant products and the production of pharmaceutical and specialty chemicals}

Many tree fruits contain essential nutrients such as folate and ascorbic acid while also producing many nutraceutical compounds such as flavonoids, polyphenols, and carotenoids (Karasawa and Mohan 2018). Metabolic engineering of fruit nutritional quality and postharvest metabolic processes not only serves to add value to the consumable product, but also to improve health worldwide. There have been several initial successes in metabolic engineering of fruit nutritional quality in common fruit-bearing woody species (Table 1). Downregulating the expression of MdMYB44, a regulator of fruit acidity in apple, increased the accumulation of malate (a key flavor component) in transient transgenic apple calli (Jia et al. 2021). Sugar accumulation in apple was promoted by suppressing aldose-6-phosphate reductase, a key enzyme promoting sorbitol biosynthesis from glucose-6-phosphate in apple (Li et al. 2018). Apple engineered to constitutively overexpress a regulator of anthocyanin biosynthesis, the MdWRKY11 transcription factor, 
demonstrated high anthocyanin accumulation and red coloration in fruit flesh (Liu et al. 2019; Pons et al.2014). In another study, sweet orange was engineered with an RNAi construct to inhibit $\beta$-carotene hydroxylase activity, resulting in higher accumulation of $\beta$-carotene (a provitamin A carotenoid) in the fruit due to its reduced conversion to xanthophylls. This RNAi construct was transformed alongside of a FLOWERING LOCUS T (FT) overexpression cassette to considerably shorten the seed-to-seed time in the resulting lines (Pons et al. 2014).

Beyond nutritional compounds, woody plants synthesize a wealth of health-promoting medicinal compounds. Many such medicinal compounds are economic targets for metabolic engineering (Table 1) in addition to the outstanding examples of the anticancer drug paclitaxel from pacific yew tree (Taxus brevifolia) and the vaccine adjuvant QS-21 from Quillaja saponaria. Some chemical classes represented in woody plants used in herbalism are quinoline alkaloids (Such as those from the cinchona tree: cinchonine, cinchonidine, quinidine, and the antimalarial agent quinine)\{Dey, $2020 \# 281$, isoquinoline alkaloids (such as the anticancer and antiviral compound berberine from Berberis species), purine alkaloids (including caffeine from coffee trees, theophylline from tea plants and theobromine from cacao plants), benzophenones (the major bioactive compounds in mango leaves which are used to treat diabetes), and flavonoids (Dey et al. 2020; Neag et al. 2018; Zhang et al. 2019). Metabolic engineering is also central to the effort of increasing yields of specialty chemicals, such as components of fragrance and essential oils. For instance, with an aim of improving overall monoterpene production, the Perilla frutescens limonene synthase was overexpressed in Eucalyptus camaldulensis with a plastidic or cytosolic localization, resulting in over a threefold increase in limonene production alongside of increased accumulation of two other major monoterpenes, which are valued components of Eucalyptus essential oils (Ohara et al. 2010). On the other hand, "undesirable" metabolites can be reduced in woody plants through metabolic engineering. Transgenic coffee (Coffea arabica and C. canephora) expressing an RNAi construct suppressing 7-N-methylxanthine methyltransferase showed up to a $50 \%$ reduction in caffeine content in embryonic tissues and plantletsopening the door to naturally decaffeinated coffee (Ogita et al. 2004).

\section{Providing sources of renewable energy}

Woody plants are a key second-generation biofuelserving as a feedstock for both bioethanol and biodiesel production (Carriquiry et al. 2011). Two of the most desirable characteristics of woody plants for biofuel production are rapid growth rate and ability to be coppiced. Hybrid poplar (Populus spp.) and willow (Salix spp.) grow quickly and tolerate coppicing well, making them good targets of metabolic engineering for biofuel production. As high lignin content constrains the effectiveness of chemical pulping and of lignocellulosic ethanol production, ideal woody feedstocks for this process would also have optimal cellulose and lignin compositions and benefit from the redirection of metabolites away from lignin biosynthesis (Mahon and Mansfield 2019; Van Acker et al. 2014). The benefits of redirecting metabolic flux are potentially twofold: the energy demands of lignin biosynthesis can be lowered while simultaneously increasing the ease that valuable compounds can be harvested from the woody plant material. Suppression of enzymes responsible for lignin precursor production in transgenic poplar decreased the accumulation of insoluble lignin (Bjurhager et al. 2010; Coleman et al. 2008; Van Acker et al. 2014). In one study, this also increased the presence of soluble products including many phenylpropanoid glycosides (Coleman et al. 2008). In another study, this reduction of insoluble lignin fraction improved the ethanol yield of the fermented biomass, but with reduced biomass yield (Van Acker et al. 2014). As such, modifying lignin metabolism is a promising frontier to facilitate chemical production in woody plants, though the trade-off between the lignin reduction and sustained growth of the plants warrants further investigation.

Oil producing woody species such as palm (Elaeis guineensis) and Jatropha curcas are promising sources of biodiesel (Carriquiry et al. 2011). Current efforts are underway to engineer palm trees with enhanced production of oleic acid and with generally reduced saturated fatty acids (Rasid et al. 2020). In J. curcas, triacylglycerol (TAG) catabolism was suppressed by downregulating a lipase via RNAi, resulting in higher storage lipid accumulation in seeds (Kim et al. 2014). TAG accumulation in J. curcas seeds was also increased by overexpressing Arabidopsis diacylglycerol acyltransferase 1, a committed step in TAG biosynthesis (Maravi et al. 2016). Finally, RNAi cassettes have also been leveraged in J. curcas to stably lower the expression of toxic curcin proteins in the seeds, addressing the safety concerns of jatropha processing (Gu et al. 2015). These approaches highlight possibilities in long-lived oil 
producing species as transformation and regeneration tools become more standardized and widely implemented.

\section{DEVELOPMENT OF MODEL SYSTEMS AND OMICS AND SYSTEMS BIOLOGY TOOLS TO EXPEDITE METABOLIC ENGINEERING OF WOODY PLANTS}

\section{Utility of model systems and omics approaches in metabolic engineering of woody plants}

With the availability of various genetic, genomic, and biochemical tools, poplar have emerged as suitable model systems for woody plant biology, particularly for important tree-specific traits such as crown size, trunk diameter, and wood density. Multiple annotated, high coverage genome sequences exist for Populus species, such as $P$. trichocarpa, $P$. deltoides, $P$. tremula $\times$ alba hybrid, $P$. euphratica, and P. tremula (Osakabe et al. 2016; Tuskan et al. 2018). A subset of these genomes and a standardized gene expression atlas of P. trichocarpa are also integrated into the Phytozome platform for easier exploration (Goodstein et al. 2012). The availability of reference genomes expediate the sequencing-based methylome analysis to study the epigenetic control of metabolism. For example, high coverage genome-wide cytosine methylation maps and transcriptomic profiling of $P$. trichocarpa stems in different developmental stages were generated and compared to understand the roles of methylation in wood formation (Zhang et al. 2020). Whole-genome resequencing of outcrossing woody plants including poplar can be leveraged to map agronomically important loci using the recently developed OutcrossSeq method (Chen et al. 2021). In this method, a pair of founder parents are sequenced with high resolution, with progeny individuals from the founder cross sequenced at low coverage to produce haplotypes suitable for genetic mapping using fastGWA (Jiang et al. 2019). OutcrossSeq was validated on a biparental cross in walnut Uuglans regia) and can be extended to metabolic phenotypes that are potential targets of metabolic engineering not only in walnut, but also in other highly heterozygous woody plant species for which a reference genome exists (Chen et al. 2021).

Phenotypic data are critical when using the growing collection of woody plant genomic information to unravel the function of structural and regulatory genes for metabolic engineering. Plant phenomics is increasingly capable of meeting this need for phenotypic information because of recent advances in computing power and applications of computer vision. Classical image-based methods are useful for phenotyping smaller, more easily managed woody plant species such as grape (Underhill et al. 2020) and Camellia sinensis (Hazra et al. 2018). Image-based approaches for analyzing canopy growth from ground level are also available for tree species. A maintained online repository of these image-based tools can be found at Quantitativeplant.org (Lobet et al. 2013). Camera-equipped unmanned aerial vehicles (UAVs) can capture phenotypes otherwise inaccessible from the ground. Use of infrared cameras expands the collection to phenotypes available to researchers to spectral indices that can serve as suitable proxies for chemical composition. These include the modified simple ratio for chlorophyll content (Wu et al. 2008), anthocyanin reflectance index for anthocyanin pigment compounds (Gitelson et al. 2001), and the photochemical reflectance index for light absorbing compounds such as xanthophylls and carotenoids (Peñuelas et al. 2011). A clear limitation for implementing common phenomics tools into metabolic engineering efforts is their restriction to visible phenotypes. Subtle changes in metabolic flux are unlikely to result in clear changes in color or morphology. However, the association of a clear morphological or phenological phenotype with a controlled metabolic change raises the possibility of leveraging phenomics-based approaches as a fast, low-cost way to screen whole plots of woody plants. Ongoing work in this area will expand the availability and validation of spectral indices that are correlated with chemical content-thus affording more utility to the UAV-based systems that are already an asset to woody plant management.

Knowledge of both genetic and phenotypic data for species such as poplar opens the door to functional genomics in woody plants, which informs metabolic engineering. Genetic polymorphisms including common and rare variants have been identified in accessions covering wide latitudinal range of Populus species (Geraldes et al. 2013; Piot et al. 2020). Genome-wide association studies (GWAS) have taken advantage of these accessions to understand quantitative traits and, combined with the metabolic and phenomic data, to study the genetic regulation of metabolites (Geraldes et al. 2013; Piot et al. 2020). Systems biology approaches have integrated genetic and multi-omics information to uncover key players such as biosynthetic genes and transcription factors involved in the regulatory network (Myburg et al. 2019). In one application, integrated omics analysis was applied to transgenic poplar lines in which 21 lignin pathway genes were perturbed to predict traits associated with wood formation for improved lignin and wood properties in tree species (Wang et al. 2018a). Extensions of this work could be 
found in other metabolites linked to plant performance such as phenolics, carotenoids, and lipids.

Metabolic flux analysis examines intracellular carbon flows and constitutes an integral component of systems biology modeling. The long-distance transportation of metabolites through the extended vascular system of woody plants makes simulation of whole-plant metabolism using single cell models more challenging. Thus, modifications to the pipelines established in herbaceous model plants is needed (Junker 2014; Zhang et al. 2018). Work in poplar has nonetheless taken advantage of metabolic flux analysis to unpack the metabolic response to low nitrogen, elucidating a higher flux through the tricarboxylic acid (TCA) cycle and lower flux into nitrogen storage proteins under reduced nitrogen (Zhang et al. 2018). In another interesting example in woody plants, metabolic flux in transgenic poplar with suppressed isoprene synthase was compared to wild-type plants. This work found substantially reduced isoprene emission and increases in metabolic investment into chlorophyll and carotenoid pigments in the transgenic plants (Ghirardo et al. 2014). Overall, this plethora of genetic and omics information in Populus species enables exploratory studies of woody plant functional genomics even prior to experimental design in other woody systems. These pipelines and their findings can thus be transferred from woody model systems to other less-studied woody plants.

\section{Application of gene editing tools propelled by advances in transformation and regeneration of woody plants}

Metabolic engineering often involves manipulating gene expression and function in plants. As a widely used gene editing technology, clustered regularly interspaced short palindromic repeats/CRISPR-associated protein 9 (CRISPR-Cas9) endonuclease systems have been used in woody plants such as poplar (Populus tomentosa Carr.), mandarin orange (Citrus reticulata), apple, pear (Pyrus communis), and grape (Charrier et al. 2019; Fan et al. 2015; Osakabe et al. 2016; Sandhya et al. 2020; Wang et al. 2018b). A great advantage of (modified) CRISPRCas9 is that multiple genes and gene homoeologs (in polyploid species) can be edited simultaneously in woody plants where pyramiding multiple gene mutations/overexpression by crossing is often not feasible (Armario Najera et al. 2019). In addition, homozygous mutations are possible as early as the $\mathrm{T}_{0}$ generation, and the otherwise low likelihood of this occurring can be improved using two or more guide RNAs targeting the same gene-an approach that has been successfully applied in multiple woody plants including poplar and grape (Fan et al. 2015; Wang et al. 2018b). Recently, Cas9-derived base editors have been developed and validated in poplar hybrids, which further expand the usage of CRISPR-Cas9 system in high efficient and precise genome editing in woody plants (Li et al. 2021). The expansion of CRISPR-Cas9 application to woody plants allows also more thorough exploration of biosynthetic enzymes and their regulation, which are currently understudied.

Despite the promise of gene editing technology, the transformation and regeneration of woody plants are challenging which poses a bottleneck to the application of CRISPR-Cas 9 technologies in woody plants. To this end, methods for transforming and regenerating otherwise recalcitrant woody species are steadily being developed. Agroinfiltration into aerial tissues has been used successfully to derive stable transformants in woody plants such as poplar (Stettler et al. 1996), Eucalyptus spp. (Spokevicius et al. 2005; Tournier et al. 2003), oil palm (Masani et al. 2018; Yarra et al. 2019), grape (Das et al. 2002; Li et al. 2008), Pinus taeda (Wenck et al. 1999), and others. Infiltration of Agrobacterium into seedling tissues or extracted embryos has also proven successful in species such as peach and eastern white pine (Pinus strobus) (Ricci et al. 2020; Tang et al. 2007). Poor regeneration frequencies from aerial tissue remain an issue, however, for many woody plant species, and the success in regenerating woody plants from leaves has been found to be dependent on the genetic background in a few species (Stettler et al. 1996; Tournier et al. 2003).

Besides aerial tissues, hairy root tissue has proven to be an asset for genetic transformation of woody plants. Inoculating wounded plants with Agrobacterium rhizogenes induces the formation of hairy roots that can be cultured and regenerated into viable plants (Tepfer 1990). In purple willow (Salix purpurea), transformation efficiencies using hairy root culture far exceeded aerial tissues, showing efficiencies over $80 \%$ alongside of higher regeneration rates (Gomes et al. 2019). Highly effective transformation and regeneration protocols using hairy roots induced by $A$. rhizogenes have been demonstrated in several systems including Eucalyptus (Plasencia et al. 2016), Poplar (Yoshida et al. 2015), and Camellia sinensis (Alagarsamy et al. 2018). The efficacy of this method combined with the ability to introduce multi-gene cassettes using $A$. rhizogenes will make it a staple in woody plant genetic and metabolic engineering.

To promote regeneration of woody plant tissues, plant developmental regulators, which are transcription factors involved in reprograming cell fates, makes the metabolic engineering possible in some difficult to 
regenerate woody plants (Ikeuchi et al. 2019). Overexpressing developmental genes such as GROWTH-REGULATING FACTOR 4 (GRF4), GRF-INTERACTING FACTOR 1 (GIF1), LEAFY COTYLEDON 1 (LEC1), WUSCHEL, and $B A B Y$ BOOM (BBM) successfully improved the regeneration of Arabidopsis (Boutilier et al. 2002; Lotan et al. 1998; Luo and Palmgren 2021; Zuo et al. 2002). Similar strategies have also been tested in woody plants through ectopic expression of GRF-GIF chimeras in citrus (Debernardi et al. 2020); LEC2 and BBM in Theobroma cacao (Florez et al. 2015; Shires et al. 2017); and $B B M$ in Poplar (Deng et al. 2009), among others. Manipulating developmental regulators should be done with caution; however, as they may affect the development of newly generated transgenic plants. In T. cacao, in spite of the significant improvement in early stages of embryogenesis, homologous overexpression of $B B M$ in cotyledons led to the occurrence of abnormal cotyledon development (Florez et al. 2015). An interesting new development in multiple dicotyledonous plant species including grape is that combinations of developmental regulators can be expressed through de novo meristem induction thus bypassing the need of in vitro tissue culture (Maher et al. 2020). These strategies need to be further tested and improved upon in additional woody plant species to explore and mitigate broader developmental issues caused by manipulating growth regulators for improved regeneration.

In addition to the aforementioned developmental regulators, additional factors have been applied to reduce the long juvenile period and promote flowering in woody plants to expedite breeding. For instance, the overexpression of BPMADS4 successfully reduced the juvenile period and promoted early flowering in apple (Flachowsky et al. 2007). Ectopic expression of FT from many donor species has reduced the generation time woody species including plum (Prunus domestica) (Petri et al. 2018; Srinivasan et al. 2012), Eucalyptus grandis $\times$ E. urophylla hybrids (Klocko et al. 2016), and sweet orange (Pons et al. 2014). Overexpression of Arabidopsis APETALA1 (AP1) shortened the generation time to one year in sweet orange and citrange (a hybrid of sweet orange and trifoliate orange; Citrus sinensis $\times$ Poncirus trifoliata). In the case of citrange, the transgenic plants were used in re-transformation to test gene stacking; the reporter genes were stably expressed in the re-transformant and were evaluated as early as one year (Cervera et al. 2009). The success of these approaches at substantially lowering generation time in woody species raises promise for introducing useful traits such as disease resistance from wild species or other elite lines.

\section{METABOLIC ENGINEERING OF AGRONOMICALLY AND ECONOMICALLY VIABLE WOODY PLANTS IS ENHANCED BY MODERN BREEDING TOOLS}

Traditional crossing and evaluation methods remain indispensable for facilitating metabolic engineering of woody plants because of their ability to combine locally adapted traits into engineered lines expressing a particular suite of biosynthetic and regulatory genes. Woody plant breeding is naturally hindered by the long time period before reproductive maturity and before meaningful phenotypic evaluation can occur. Strategies common in annual plant breeding such as "speed breeding" (Watson et al. 2018) and usage of off-season nurseries are not generally viable for woody species. An expanding toolkit of computational and engineering tools ameliorate this constraint and collectively speed up the process of traditional breeding in long-lived woody plants. Phenomic and genomic data for woody plants are central to this effort by collectively facilitating quantitative genetic approaches to breeding including genomic selection (GS) - that is, selection on whole genomes in highly heterogeneous populations (Lebedev et al. 2020). In this approach, genome-estimated breeding values (GEBVs) are estimated from genetic data (e.g. SNP arrays, whole genome sequences) and known phenotypes using statistical models such as Bayes Least Absolute Shrinkage and Selection Operator (Bayes LASSO) (Park and Casella 2008) and Ridge Regression Best Linear Unbiased Predictor (RR-BLUP) (Endelman 2011). Approaches using either family of models are increasingly relevant to breeding and can be applied effectively to woody plants.

Growth traits such as height, wood density, bark thickness, stem straightness, and circumference have been predicted in woody plant progeny with suitable accuracy using GS (de Moraes et al. 2018; Li et al. 2019b; Thistlethwaite et al. 2020). In addition, GS has also been used to predict yield in significant agricultural crops such as macadamia (Macadamia integrifolia $\times$ tetraphylla) and passion fruit (Passiflora edulis) (O'Connor et al. 2018; Viana et al. 2017). Finally, black spot resistance in pear progeny has been adequately predicted using multiple Bayesian GS models (Iwata et al. 2013). GS can also be applied to metabolic phenotypes, which has been demonstrated for anthocyanin content in maize and glucosinolate content in Brassica napus (Chatham and Juvik 2020; Werner et al. 2018). Using genome-wide information to predict metabolite profiles in woody plants has been relatively limited. There has been some application of GS to flavor components of grape and pear (Iwata et al. 2013; Viana et al. 2016). Recent work has also been conducted to predict 
rubber production in the progeny of rubber trees $(\mathrm{He}$ vea brasiliensis) (Cros et al. 2019). Future applications of GS to woody species can be used in functional genomics to identify target traits and breeding schemes to optimize accumulation of useful metabolites or to increase flux through a metabolic pathway that can be leveraged in engineering efforts.

\section{METABOLIC ENGINEERING BEYOND WOODY PLANTS-PRODUCING WOODY PLANT METABOLITES IN COMPLEMENTARY SYSTEMS}

To obtain valuable metabolites naturally produced by woody plants, metabolic pathways can also be reconstructed in complementary biological systems. Microorganisms are suitable for this purpose because of their small genome, simple compartments, fast growth rate, and easily controllable growth conditions. For example, the synthesis of hydroxytyrosol, a valuable nutraceutical and preservative from olive, was achieved in E. coli through the heterologous expression of the hydroxytyrosol pathway in tandem with tyrosine overproduction (Trantas et al. 2019). In another example, the production of caffeine has also been achieved by inserting xanthosine methyltransferase from Coffea arabica and caffeine synthase from Camellia sinensis into yeast strains that were fed exogenous xanthosine (Jin et al. 2014). However, lack of the native biochemical and regulatory network in the microbial systems can result in metabolic imbalance, accumulated intermediates, and toxic compounds that lead to the failure of metabolic engineering in microbial systems. Moreover, maintaining a large, sterile manufacturing platform requires often prohibitive amounts of labor and materials that complicate scaling.

Using plants as a complementary system for metabolite production is often fruitful, as the availability of the existing upstream substrates with the native gene regulatory network circumvent issues found in microbial systems. The production of woody plant metabolite taxadiene (the first committed intermediate in the synthesis of taxol/paclitaxel, an anticancer drug) was boosted in multiple complementary plant systems that produce carotenoids such as tomato (Solanum lycopersicum) (Cha et al. 2012; Kovacs et al. 2007; Li et al. 2015). Taxadiene and carotenoids use the common biosynthetic precursor geranylgeranyl diphosphate (GGPP). By expressing the taxadiene synthase in a yellow flesh tomato with low accumulation of carotenoids due to lacking a functional phytoene synthase (the rate limiting enzyme for carotenoid biosynthesis), metabolic flux was redirected from carotenoid to taxadiene biosynthesis and resulted in high amounts of taxadiene in leaves and fruits of the transgenic plants (Besumbes et al. 2004; Kovacs et al. 2007). In another study, the accumulation of biosynthetic intermediates of taxol, taxadiene, and taxadiene- $5 \alpha-o l$, was significantly improved in Nicotiana benthamiana leaves by enriching the isoprenoid precursor for taxol biosynthesis and engineering enzymes for taxol biosynthesis in the same compartment (Li et al. 2019a).

The success above highlights the possibilities when many components of a biosynthetic pathway are known. However, de novo biosynthesis of woody plant metabolites in complementary systems can be challenging when the biosynthetic pathway is not fully elucidated (such as QS-21 and quinine). To this end, biosynthetic precursors and their derivatives can be fed to the complementary systems to produce downstream products (Cravens et al. 2019). Alternatively, pathway intermediates produced by the complementary systems can be extracted and used as substrates for in vitro reactions that produce the target woody plant metabolites (Birchfield and McIntosh 2020; Cravens et al. 2019). Metabolites that function in preserving the health of plant tissues or otherwise maintaining physiological roles are not suitable for production in heterologous plant expression systems, as extraction removes them from the context in which they are the most valuable. This applies to an array of compounds involved in flower color, lignin production, water homeostasis, and signaling. Nonetheless, heterologous systems remain useful for engineering efforts in which a purified final product is the central aim.

\section{CONCLUDING REMARKS AND FUTURE PERSPECTIVES}

Pivotal discoveries in herbaceous model systems such as Arabidopsis, tobacco, and tomato can help chart the course for research in woody species. Ongoing work in model systems is optimizing the delivery of multiple genes concurrently-which raises the possibility of circumventing multiple regeneration events for recalcitrant woody plants. Gene Assembly in Agrobacterium by Nucleic Acid Transfer using Recombinase Technology (GAANTRY) uses multiple unidirectional site-specific recombinases to stack multiple genes in vivo. The GAANTRY ArPORT1 strain of $A$. rhizogenes was demonstrated to be effective at stacking up to ten genes in rice (Hathwaik et al. 2021). As A. rhizogenes has proven effective at transforming woody plants (Gomes et al. 2019), the GAANTRY system could prove useful for reconstituting metabolic pathways into woody plant 
chasses. Plant Artificial Chromosomes (PACs) are stable in plant cells and multiple genes on artificial chromosomes can be stably expressed. PACs have been the subject of research in non-woody plants such as barley, maize, and Arabidopsis, and promise remains for implementing PACs into woody plant species with established transformation and regeneration methods (Yu et al. 2016). Delivery of CRISPR-Cas 9 systems is also being expanded, with viral delivery systems already developed and nanoparticle or nanotube delivery on the horizon (Demirer et al. 2021), facilitating the metabolic engineering effort in woody plants.

Though gene regulatory networks have been extensively explored in herbaceous plants, considerable work remains to gain a more complete understanding of such regulatory networks in woody plants. The task of unraveling these networks in woody plant species is complicated by the diversity of tissue types present as well as the maturation time needed for such gene networks to emerge and be adequately explored. Poplar serves as a suitable woody model plant from which findings can be translated. Methods and knowledge developed in poplar can prove instrumental in exploring other woody plant systems to bolster our knowledge of their metabolic networks and to translate suitable approaches for metabolic engineering. Conquering the bottlenecks of transformation and regeneration in nonmodel woody plants will shorten the design-build-testlearn cycles in gene editing and transgene insertion to streamline their usage in metabolic engineering as well. Finally, a large amount of untapped diversity exists in domesticated cultivars across broad geographic ranges and non-domesticated genotypes. Comparative genomics can take advantage of the highly diverse genomes of woody species around the globe not only for breeding, but also to study the evolution of genes and gene families to facilitate gene mining for metabolic engineering (Tuskan et al. 2018).

As woody plants are understudied, there is room to integrate current genetic and metabolic engineering strategies developed in other plant and microbial systems. Implementation of these strategies is finding increasing success in more studied woody plant systems such as poplar and citrus. Translating these tools into more woody plant systems not only leverages different native metabolic networks, but also expands the collection of ecosystem services available to the site of interest due to the broader species selection. These ecosystem services brought by woody plants are unique among plant chemical factories and include habitat, carbon sequestration, erosion reduction, and water retention. These ecosystem services can be viewed as the key benefits of a sustainable bioeconomy anchored in the used of long-lived woody plants. Low resource and labor demand further complement the vast ecosystem services of woody plant platforms. Metabolic engineering expedites our capability to simultaneously capitalize on the rich biochemical diversity of woody plants in tandem with the suite of environmental benefits associated with their usage. The transition from an oil-based economy to a sustainable bio-based economy will be facilitated by advances in this space.

Acknowledgements We would like to thank funding support from USDA-NIFA to LT (2017-67013-26164), and the Henry A. Jastro Research Award, and the UC Davis, Department of Plant Sciences Graduate Research Fellowship to CSB.

Author contributions SY and LT conceived the review article. SY, CSB, and LT wrote the draft. All authors have read, edited, and approved publication of the present paper.

\section{Declarations}

Conflict of interest The authors declare that they have no conflict of interest.

Open Access This article is licensed under a Creative Commons Attribution 4.0 International License, which permits use, sharing, adaptation, distribution and reproduction in any medium or format, as long as you give appropriate credit to the original author(s) and the source, provide a link to the Creative Commons licence, and indicate if changes were made. The images or other third party material in this article are included in the article's Creative Commons licence, unless indicated otherwise in a credit line to the material. If material is not included in the article's Creative Commons licence and your intended use is not permitted by statutory regulation or exceeds the permitted use, you will need to obtain permission directly from the copyright holder. To view a copy of this licence, visit http://creativecommons.org/ licenses/by/4.0/.

\section{References}

Alagarsamy K, Shamala LF, Wei S (2018) Protocol: high-efficiency in-planta Agrobacterium-mediated transgenic hairy root induction of Camellia sinensis var. sinensis. Plant Methods 14:17. https://doi.org/10.1186/s13007-018-0285-8

Alquézar B et al (2021) Engineered orange ectopically expressing the Arabidopsis $\beta$-caryophyllene synthase is not attractive to Diaphorina citri, the vector of the bacterial pathogen associated to Huanglongbing. Front Plant Sci 12:200. https://doi. org/10.3389/fpls.2021.641457

Armario Najera V, Twyman RM, Christou P, Zhu C (2019) Applications of multiplex genome editing in higher plants. Curr Opin Biotech 59:93-102. https://doi.org/10.1016/j. copbio.2019.02.015

Baucher M et al (1996) Red xylem and higher lignin extractability by down-regulating a cinnamyl alcohol dehydrogenase in poplar. Plant Physiol 112:1479-1490. https://doi.org/10. 1104/pp.112.4.1479

Besumbes O, Sauret-Güeto S, Phillips MA, Imperial S, RodríguezConcepción M, Boronat A (2004) Metabolic engineering of 
isoprenoid biosynthesis in Arabidopsis for the production of taxadiene, the first committed precursor of Taxol. Biotechnol Bioeng 88:168-175. https://doi.org/10.1002/bit.20237

Birchfield AS, McIntosh CA (2020) Metabolic engineering and synthetic biology of plant natural products-a minireview. Curr Plant Biol 24:100163. https://doi.org/10.1016/j.cpb. 2020.100163

Bjurhager I et al (2010) Ultrastructure and mechanical properties of Populus wood with reduced lignin content caused by transgenic down-regulation of cinnamate 4-hydroxylase. Biomacromol 11:2359-2365. https://doi.org/10.1021/ bm100487e

Boutilier $\mathrm{K}$ et al (2002) Ectopic expression of BABY B00M triggers a conversion from vegetative to embryonic growth. Plant Cell 14:1737-1749. https://doi.org/10.1105/tpc.001941

Bryant ND et al (2020) Transgenic poplar designed for biofuels. Trends Plant Sci 25:881-896. https://doi.org/10.1016/j. tplants.2020.03.008

Burlacu E, Nisca A, Tanase C (2020) A comprehensive review of phytochemistry and biological activities of quercus species. Forests 11:904

Carriquiry MA, Du X, Timilsina GR (2011) Second generation biofuels: economics and policies. Energy Policy 39:4222-4234. https://doi.org/10.1016/j.enpol.2011.04.036

Cervera M, Navarro L, Peña L (2009) Gene stacking in 1-yearcycling APETALA1 citrus plants for a rapid evaluation of transgenic traits in reproductive tissues. J Biotechnol 140:278-282. https://doi.org/10.1016/j.jbiotec.2009.01.024

Cha M, Shim SH, Kim SH, Kim OT, Lee SW, Kwon SY, Baek KH (2012) Production of taxadiene from cultured ginseng roots transformed with taxadiene synthase gene. BMB Rep 45:589-594. https://doi.org/10.5483/bmbrep.2012.45.10. 085

Charrier A, Vergne E, Dousset N, Richer A, Petiteau A, Chevreau E (2019) Efficient targeted mutagenesis in apple and first time edition of pear using the CRISPR-Cas9 system. Front Plant Sci 10:40. https://doi.org/10.3389/fpls.2019.00040

Chatham L, Juvik J (2020) Gwas and genomic selection for increased anthocyanin content in purple corn. BioRxiv. https://doi.org/10.1101/2020.05.20.107359

Chelli-Chaabouni A (2014) Mechanisms and adaptation of plants to environmental stress: a case of woody species. In: Ahmad P, Wani M (eds) Physiological mechanisms and adaptation strategies in plants under changing environment, vol 1. Springer, New York, pp 1-24

Chen $\mathrm{M}$ et al (2021) Genome-wide identification of agronomically important genes in outcrossing crops using OutcrossSeq. Mol Plant 14(4):556-570. https://doi.org/10.1016/j.molp.2021. 01.003

Choi KR, Jiao S, Lee SY (2020) Metabolic engineering strategies toward production of biofuels. Curr Opin Chem Biol 59:1-14. https://doi.org/10.1016/j.cbpa.2020.02.009

Coleman HD, Canam T, Kang KY, Ellis DD, Mansfield SD (2007) Over-expression of UDP-glucose pyrophosphorylase in hybrid poplar affects carbon allocation. J Exp Bot 58:4257-4268. https://doi.org/10.1093/jxb/erm287

Coleman HD, Park JY, Nair R, Chapple C, Mansfield SD (2008) RNAi-mediated suppression of $p$-coumaroyl-CoA 3'-hydroxylase in hybrid poplar impacts lignin deposition and soluble secondary metabolism. Proc Natl Acad Sci USA 105:4501-4506. https://doi.org/10.1073/pnas.0706537105

Coutos-Thévenot $\mathrm{P}$ et al (2001) In vitro tolerance to Botrytis cinerea of grapevine 41B rootstock in transgenic plants expressing the stilbene synthase Vst1 gene under the control of a pathogen-inducible PR 10 promoter. J Exp Bot 52:901-910. https://doi.org/10.1093/jexbot/52.358.901
Cravens A, Payne J, Smolke CD (2019) Synthetic biology strategies for microbial biosynthesis of plant natural products. Nat Commun 10:2142. https://doi.org/10.1038/s41467-01909848-w

Cros D et al (2019) Within-family genomic selection in rubber tree (Hevea brasiliensis) increases genetic gain for rubber production. Ind Crop Prod 138:111464. https://doi.org/10. 1016/j.indcrop.2019.111464

Dalton DA, Ma C, Shrestha S, Kitin P, Strauss SH (2011) Trade-offs between biomass growth and inducible biosynthesis of polyhydroxybutyrate in transgenic poplar. Plant Biotechnol J 9:759-767. https://doi.org/10.1111/j.1467-7652.2010. 00585.x

Dandekar AM et al (2004) Effect of down-regulation of ethylene biosynthesis on fruit flavor complex in apple fruit. Transgenic Res 13:373-384. https://doi.org/10.1023/B:TRAG. 0000040037.90435 .45

Das D, Reddy M, Upadhyaya K, Sopory S (2002) An efficient leafdisc culture method for the regeneration via somatic embryogenesis and transformation of grape (Vitis vinifera L.). Plant Cell Rep 20:999-1005. https://doi.org/10.1007/ s00299-002-0441-4

de Moraes BFX et al (2018) Genomic selection prediction models comparing sequence capture and SNP array genotyping methods. Mol Breed 38:115. https://doi.org/10.1007/ s11032-018-0865-3

Debernardi JM, Tricoli DM, Ercoli MF, Hayta S, Ronald P, Palatnik JF, Dubcovsky J (2020) A GRF-GIF chimeric protein improves the regeneration efficiency of transgenic plants. Nat Biotechnol 38:1274-1279. https://doi.org/10.1038/s41587-0200703-0

Demirer GS et al (2021) Nanotechnology to advance CRISPR-Cas genetic engineering of plants. Nat Nanotechnol 16:243-250. https://doi.org/10.1038/s41565-021-00854-y

Deng W, Luo K, Li Z, Yang Y (2009) A novel method for induction of plant regeneration via somatic embryogenesis. Plant Sci 177:43-48. https://doi.org/10.1016/j.plantsci.2009.03.009

Dey $\mathrm{P}$ et al (2020) Analysis of alkaloids (indole alkaloids, isoquinoline alkaloids, tropane alkaloids). In: Sanches Silva A, Nabavi SF, Saeedi M, Nabavi SM (eds) Recent advances in natural products analysis. Elsevier, Amsterdam, pp 505-567

Dubouzet JG, Strabala TJ, Wagner A (2013) Potential transgenic routes to increase tree biomass. Plant Sci 212:72-101. https://doi.org/10.1016/j.plantsci.2013.08.006

Endelman JB (2011) Ridge regression and other kernels for genomic selection with $\mathrm{R}$ package rrBLUP. Plant Genome 4:250-255. https://doi.org/10.3835/plantgenome2011.08. 0024

Espley RV, Hellens RP, Putterill J, Stevenson DE, Kutty-Amma S, Allan AC (2007) Red colouration in apple fruit is due to the activity of the MYB transcription factor, MdMYB10. Plant J 49:414-427. https://doi.org/10.1111/j.1365-313X.2006. 02964.x

Fan C, Pu N, Wang X, Wang Y, Fang L, Xu W, Zhang J (2008) Agrobacterium-mediated genetic transformation of grapevine (Vitis vinifera L.) with a novel stilbene synthase gene from Chinese wild Vitis pseudoreticulata. Plant Cell Tiss Organ Cult 92:197-206. https://doi.org/10.1007/s11240-007-9324-2

Fan D, Liu T, Li C, Jiao B, Li S, Hou Y, Luo K (2015) Efficient CRISPR/Cas9-mediated targeted mutagenesis in populus in the first generation. Sci Rep 5:12217. https://doi.org/10. 1038/srep12217

Fenn MA, Giovannoni JJ (2021) Phytohormones in fruit development and maturation. Plant J 105:446-458. https://doi.org/ 10.1111/tpj.15112 
Flachowsky H, Peil A, Sopanen T, Elo A, Hanke V (2007) Overexpression of BpMADS4 from silver birch (Betula pendula Roth.) induces early-flowering in apple (Malus $\times$ domestica Borkh.). Plant Breed 126:137-145. https://doi. org/10.1111/j.1439-0523.2007.01344.x

Florez SL, Erwin RL, Maximova SN, Guiltinan MJ, Curtis WR (2015) Enhanced somatic embryogenesis in Theobroma cacao using the homologous BABY BOOM transcription factor. BMC Plant Biol 15:121. https://doi.org/10.1186/s12870-015-0479-4

Gao M, Sakamoto A, Miura K, Murata N, Sugiura A, Tao R (2000) Transformation of Japanese persimmon (Diospyros kaki Thunb.) with a bacterial gene for choline oxidase. Mol Breed 6:501-510. https://doi.org/10.1023/A:1026513831290

Gao M, Tao R, Miura K, Dandekar AM, Sugiura A (2001) Transformation of Japanese persimmon (Diospyros kaki Thunb.) with apple cDNA encoding NADP-dependent sorbitol-6-phosphate dehydrogenase. Plant Sci 160:837-845. https://doi.org/10.1016/s0168-9452(00)00458-1

Geraldes A et al (2013) A 34K SNP genotyping array for Populus trichocarpa: design, application to the study of natural populations and transferability to other populus species. Mol Ecol Resour 13:306-323. https://doi.org/10.1111/ 1755-0998.12056

Ghirardo A et al (2014) Metabolic flux analysis of plastidic isoprenoid biosynthesis in poplar leaves emitting and nonemitting isoprene. Plant Physiol 165:37-51. https://doi.org/ $10.1104 /$ pp.114.236018

Giorcelli A et al (2004) Expression of the stilbene synthase (StSy) gene from grapevine in transgenic white poplar results in high accumulation of the antioxidant resveratrol glucosides. Transgenic Res 13:203-214. https://doi.org/10.1023/B: TRAG.0000034658.64990.7f

Gitelson AA, Merzlyak MN, Chivkunova OB (2001) Optical properties and nondestructive estimation of anthocyanin content in plant leaves. Photochem Photobiol 74:38-45. https://doi. org/10.1562/0031-8655(2001)074\%3c0038:opaneo\%3e2. $0 . \mathrm{co} ; 2$

Gomes C, Dupas A, Pagano A, Grima-Pettenati J, Paiva JAP (2019) Hairy root transformation: a useful tool to explore gene function and expression in Salix spp. recalcitrant to transformation. Front Plant Sci 10:1427. https://doi.org/10.3389/ fpls.2019.01427

Goodstein DM et al (2012) Phytozome: a comparative platform for green plant genomics. Nucl Acids Res 40:D1178-D1186. https://doi.org/10.1093/nar/gkr944

Gu K, Tian D, Mao H, Wu L, Yin Z (2015) Development of markerfree transgenic Jatropha curcas producing curcin-deficient seeds through endosperm-specific RNAi-mediated gene silencing. BMC Plant Biol 15:242. https://doi.org/10.1186/ s12870-015-0625-z

Hathwaik LT, Thomson JG, Thilmony R (2021) Gene assembly in Agrobacterium via nucleic acid transfer using recombinase technology (GAANTRY). Methods Mol Biol 2238:3-17. https://doi.org/10.1007/978-1-0716-1068-8_1

Hazra A, Dasgupta N, Sengupta C, Das S (2018) Next generation crop improvement program: progress and prospect in tea (Camellia sinensis (L.) 0. Kuntze). Ann Agrar Sci 16:128-135. https://doi.org/10.1016/j.aasci.2018.02.002

Huntley SK, Ellis D, Gilbert M, Chapple C, Mansfield SD (2003) Significant increases in pulping efficiency in $\mathrm{C} 4 \mathrm{H}-\mathrm{F} 5 \mathrm{H}$-transformed poplars: improved chemical savings and reduced environmental toxins. J Agric Food Chem 51:6178-6183. https://doi.org/10.1021/jf034320o

Ikeuchi M, Favero DS, Sakamoto Y, Iwase A, Coleman D, Rymen B, Sugimoto K (2019) Molecular mechanisms of plant regeneration. Annu Rev Plant Biol 70:377-406. https://doi. org/10.1146/annurev-arplant-050718-100434

Iwata H, Hayashi T, Terakami S, Takada N, Sawamura Y, Yamamoto $\mathrm{T}$ (2013) Potential assessment of genome-wide association study and genomic selection in Japanese Pear Pyrus Pyrifolia. Breed Sci 63:125-140. https://doi.org/10.1270/jsbbs.63.125

Jia D et al (2021) Genetic variation in the promoter of an R2R3-MYB transcription factor determines fruit malate content in apple (Malus domestica Borkh.). Plant Physiol 186(1):549-568. https://doi.org/10.1093/plphys/kiab098

Jiang L, Zheng Z, Qi T, Kemper KE, Wray NR, Visscher PM, Yang J (2019) A resource-efficient tool for mixed model association analysis of large-scale data. Nat Genet 51:1749-1755. https://doi.org/10.1038/s41588-019-0530-8

Jin L et al (2014) Metabolic engineering of Saccharomyces cerevisiae for caffeine and theobromine production. PLoS ONE 9:e105368. https://doi.org/10.1371/journal.pone. 0105368

Jing ZP, Gallardo F, Pascual MB, Sampalo R, Romero J, De Navarra AT, Cánovas FM (2004) Improved growth in a field trial of transgenic hybrid poplar overexpressing glutamine synthetase. New Phytol 164:137-145. https://doi.org/10.1111/ j.1469-8137.2004.01173.x

Junker BH (2014) Flux analysis in plant metabolic networks: increasing throughput and coverage. Curr Opin Biotechnol 26:183-188. https://doi.org/10.1016/j.copbio.2014.01.016

Karasawa MMG, Mohan C (2018) Fruits as prospective reserves of bioactive compounds: a review. Nat Prod Bioprospect 8:335-346. https://doi.org/10.1007/s13659-018-0186-6

Kim M, Kim S-C, Song KJ, Kim HB, Kim I-J, Song E-Y, Chun S-J (2010) Transformation of carotenoid biosynthetic genes using a micro-cross section method in kiwifruit (Actinidia deliciosa cv. Hayward). Plant Cell Rep 29:1339-1349. https:// doi.org/10.1007/s00299-010-0920-y

Kim MJ, Yang SW, Mao H-Z, Veena SP, Yin J-L, Chua N-H (2014) Gene silencing of Sugar-dependent 1 (JCSDP1), encoding a patatin-domain triacylglycerol lipase, enhances seed oil accumulation in Jatropha curcas. Biotechnol Biofuels 7:36. https://doi.org/10.1186/1754-6834-7-36

Klocko AL, Ma C, Robertson S, Esfandiari E, Nilsson O, Strauss SH (2016) FT overexpression induces precocious flowering and normal reproductive development in Eucalyptus. Plant Biotechnol J 14:808-819. https://doi.org/10.1111/pbi. 12431

Kobayashi S, Ding CK, Nakamura Y, Nakajima I, Matsumoto R (2000) Kiwifruits (Actinidia deliciosa) transformed with a Vitis stilbene synthase gene produce piceid (resveratrolglucoside). Plant Cell Rep 19:904-910. https://doi.org/10. $1007 / \mathrm{s} 002990000203$

Koeduka T et al (2013) Enhancement of production of eugenol and its glycosides in transgenic aspen plants via genetic engineering. Biochem Biophys Res Commun 436:73-78. https://doi.org/10.1016/j.bbrc.2013.05.060

Koprivova A, Kopriva S, Jäger D, Will B, Jouanin L, Rennenberg H (2002) Evaluation of transgenic poplars over-expressing enzymes of glutathione synthesis for phytoremediation of cadmium. Plant Biol 4:664-670. https://doi.org/10.1055/s2002-37399

Kovacs K, Zhang L, Linforth RS, Whittaker B, Hayes CJ, Fray RG (2007) Redirection of carotenoid metabolism for the efficient production of taxadiene [taxa-4(5),11(12)-diene] in transgenic tomato fruit. Transgenic Res 16:121-126. https://doi. org/10.1007/s11248-006-9039-x

Lebedev VG, Lebedeva TN, Chernodubov AI, Shestibratov KA (2020) Genomic selection for forest tree improvement: methods, achievements and perspectives. Forests 11:1190 
Lee C, Teng Q Huang W, Zhong R, Ye ZH (2009) Down-regulation of PoGT47C expression in poplar results in a reduced glucuronoxylan content and an increased wood digestibility by cellulase. Plant Cell Physiol 50:1075-1089. https://doi. org/10.1093/pcp/pcp060

Li ZT, Dhekney SA, Dutt M, Gray DJ (2008) An improved protocol for Agrobacterium-mediated transformation of grapevine (Vitis vinifera L.). Plant Cell Tiss Organ Cult 93:311-321. https://doi.org/10.1007/s11240-008-9378-9

Li M, Jiang F, Yu X, Miao Z (2015) Engineering isoprenoid biosynthesis in Artemisia annua L. for the production of taxadiene: a key intermediate of taxol. BioMed Res Int 2015:504932. https://doi.org/10.1155/2015/504932

Li M, Li P, Ma F, Dandekar AM, Cheng L (2018) Sugar metabolism and accumulation in the fruit of transgenic apple trees with decreased sorbitol synthesis. Hortic Res 5:60. https://doi. org/10.1038/s41438-018-0064-8

Li J, Mutanda I, Wang K, Yang L, Wang J, Wang Y (2019a) Chloroplastic metabolic engineering coupled with isoprenoid pool enhancement for committed taxanes biosynthesis in Nicotiana benthamiana. Nat Commun 10:4850. https://doi. org/10.1038/s41467-019-12879-y

Li Y, Klápště J, Telfer E, Wilcox P, Graham N, Macdonald L, Dungey HS (2019b) Genomic selection for non-key traits in radiata pine when the documented pedigree is corrected using DNA marker information. BMC Genomics 20:1026. https://doi. org/10.1186/s12864-019-6420-8

Li G, Sretenovic S, Eisenstein E, Coleman G, Qi Y (2021) Highly efficient C-to-T and A-to-G base editing in a Populus hybrid plant. Biotechnol J (in Press). https://doi.org/10.1111/pbi. 13581

Liu W et al (2019) MdWRKY11 participates in anthocyanin accumulation in red-fleshed apples by affecting MYB transcription factors and the photoresponse factor MdHY5. J Agric Food Chem 67:8783-8793. https://doi.org/10.1021/acs.jafc. 9b02920

Liu H-J et al (2021) Overexpression of JrAMT2 in walnut (Juglans regia L.) rootstock enhances nitrogen level in grafted wildtype walnut scions. Sci Hortic 280:109928. https://doi.org/ 10.1016/j.scienta.2021.109928

Lobet G, Draye X, Périlleux C (2013) An online database for plant image analysis software tools. Plant Methods 9:38. https:// doi.org/10.1186/1746-4811-9-38

Lotan T et al (1998) Arabidopsis LEAFY COTYLEDON1 is sufficient to induce embryo development in vegetative cells. Cell 93:1195-1205. https://doi.org/10.1016/s00928674(00)81463-4

Luo G, Palmgren M (2021) GRF-GIF chimeras boost plant regeneration. Trends Plant Sci 26:201-204. https://doi.org/ 10.1016/j.tplants.2020.12.001

Maher MF, Nasti RA, Vollbrecht M, Starker CG, Clark MD, Voytas DF (2020) Plant gene editing through de novo induction of meristems. Nat Biotechnol 38:84-89. https://doi.org/10. 1038/s41587-019-0337-2

Mahon EL, Mansfield SD (2019) Tailor-made trees: engineering lignin for ease of processing and tomorrow's bioeconomy. Curr Opin Biotech 56:147-155. https://doi.org/10.1016/j. copbio.2018.10.014

Maravi DK et al (2016) Ectopic expression of AtDGAT1, encoding diacylglycerol $O$-acyltransferase exclusively committed to TAG biosynthesis, enhances oil accumulation in seeds and leaves of Jatropha. Biotechnol Biofuels 9:226. https://doi.org/10. 1186/s13068-016-0642-7

Masani MYA, Izawati AMD, Rasid OA, Parveez GKA (2018) Biotechnology of oil palm: current status of oil palm genetic transformation. Biocatal Agric Biotechnol 15:335-347. https://doi.org/10.1016/j.bcab.2018.07.008

Matsunaga E et al (2012) Agrobacterium-mediated transformation of Eucalyptus globulus using explants with shoot apex with introduction of bacterial choline oxidase gene to enhance salt tolerance. Plant Cell Rep 31:225-235. https:// doi.org/10.1007/s00299-011-1159-y

Mauriat M, Moritz T (2009) Analyses of GA20ox- and GID1-overexpressing aspen suggest that gibberellins play two distinct roles in wood formation. Plant J 58:989-1003. https://doi. org/10.1111/j.1365-313X.2009.03836.x

Mellway RD, Constabel CP (2009) Metabolic engineering and potential functions of proanthocyanidins in poplar. Plant Signal Behav 4:790-792. https://doi.org/10.1104/pp.109. 139071

Mohanpuria P, Kumar V, Ahuja PS, Yadav SK (2011a) Agrobacterium-mediated silencing of caffeine synthesis through root transformation in Camellia sinensis L. Mol Biotechnol 48:235-243. https://doi.org/10.1007/s12033-010-9364-4

Mohanpuria P, Kumar V, Ahuja PS, Yadav SK (2011b) Producing low-caffeine tea through post-transcriptional silencing of caffeine synthase mRNA. Plant Mol Biol 76:523-534. https:// doi.org/10.1007/s11103-011-9785-x

Myburg AA, Hussey SG, Wang JP, Street NR, Mizrachi E (2019) Systems and synthetic biology of forest trees: a bioengineering paradigm for woody biomass feedstocks. Front Plant Sci 10:775. https://doi.org/10.3389/fpls.2019.00775

Neag MA, Mocan A, Echeverría J, Pop RM, Bocsan CI, Crişan G, Buzoianu AD (2018) Berberine: botanical occurrence, traditional uses, extraction methods, and relevance in cardiovascular, metabolic, hepatic, and renal disorders. Front Pharmacol 9:557. https://doi.org/10.3389/fphar.2018.00557

Nieminen K et al (2008) Cytokinin signaling regulates cambial development in poplar. Proc Natl Acad Sci USA 105:20032-20037. 0805617106

O'Connor K, Hayes B, Topp B (2018) Prospects for increasing yield in macadamia using component traits and genomics. Tree Genet Genomes 14:7. https://doi.org/10.1007/s11295-0171221-1

Ogita S, Uefuji H, Yamaguchi Y, Koizumi N, Sano H (2003) Producing decaffeinated coffee plants. Nature 423:823-823. https://doi.org/10.1038/423823a

Ogita S, Uefuji H, Morimoto M, Sano H (2004) Application of RNAi to confirm theobromine as the major intermediate for caffeine biosynthesis in coffee plants with potential for construction of decaffeinated varieties. Plant Mol Biol 54:931-941. https://doi.org/10.1007/s11103-004-0393-x

Ohara K, Matsunaga E, Nanto K, Yamamoto K, Sasaki K, Ebinuma H, Yazaki K (2010) Monoterpene engineering in a woody plant Eucalyptus camaldulensis using a limonene synthase cDNA. Plant Biotechnol J 8:28-37. https://doi.org/10.1111/j. 1467-7652.2009.00461.x

Oleszek M, Kowalska I, Oleszek W (2019) Phytochemicals in bioenergy crops. Phytochem Rev 18:893-927. https://doi. org/10.1007/s11101-019-09639-7

Osakabe Y, Kajita S, Osakabe K (2011) Genetic engineering of woody plants: current and future targets in a stressful environment. Physiol Plant 142:105-117. https://doi.org/10. 1111/j.1399-3054.2011.01451.x

Osakabe Y, Sugano SS, Osakabe K (2016) Genome engineering of woody plants: past, present and future. J Wood Sci 62:217-225. https://doi.org/10.1007/s10086-016-1548-5

Park T, Casella G (2008) The Bayesian Lasso. J Am Stat Assoc 103:681-686. 016214508000000337 https://doi.org/10.1198/ 
Park YW, Baba K, Furuta Y, Iida I, Sameshima K, Arai M, Hayashi T (2004) Enhancement of growth and cellulose accumulation by overexpression of xyloglucanase in poplar. FEBS Lett 564:183-187. https://doi.org/10.1016/s0014-5793(04)003 46-1

Parveez GK, Bahariah B, Ayub NH, Masani MY, Rasid OA, Tarmizi AH, Ishak Z (2015) Production of polyhydroxybutyrate in oil palm (Elaeis guineensis Jacq.) mediated by microprojectile bombardment of PHB biosynthesis genes into embryogenic calli. Front Plant Sci 6:598. https://doi.org/10.3389/fpls. 2015.00598

Peñuelas J, Garbulsky MF, Filella I (2011) Photochemical reflectance index (PRI) and remote sensing of plant $\mathrm{CO}_{2}$ uptake. New Phytol 191:596-599. https://doi.org/10.1111/j. 1469-8137.2011.03791.x

Petri C, Alburquerque N, Faize M, Scorza R, Dardick C (2018) Current achievements and future directions in genetic engineering of European plum (Prunus domestica L.). Transgenic Res 27:225-240. https://doi.org/10.1007/s11248018-0072-3

Pickett JA, Khan ZR (2016) Plant volatile-mediated signalling and its application in agriculture: successes and challenges. New Phytol 212:856-870. https://doi.org/10.1111/nph.14274

Piot A, Prunier J, Isabel N, Klápště J, El-Kassaby YA, Villarreal Aguilar JC, Porth I (2020) Genomic diversity evaluation of Populus trichocarpa germplasm for rare variant genetic association studies. Front Genet 10:1384. https://doi.org/ 10.3389/fgene.2019.01384

Placido DF et al (2019) Downregulation of a CYP74 rubber particle protein increases natural rubber production in Parthenium argentatum. Front Plant Sci 10:760. https://doi. org/10.3389/fpls.2019.00760

Plasencia A et al (2016) Eucalyptus hairy roots, a fast, efficient and versatile tool to explore function and expression of genes involved in wood formation. Plant Biotechnol J 14:1381-1393. https://doi.org/10.1111/pbi.12502

Pons E et al (2014) Metabolic engineering of $\beta$-carotene in orange fruit increases its in vivo antioxidant properties. Plant Biotechnol J 12:17-27. https://doi.org/10.1111/pbi.12112

$\mathrm{Qu} \mathrm{J}$ et al (2012) Development of marker-free transgenic Jatropha plants with increased levels of seed oleic acid. Biotechnol Biofuels 5:10. https://doi.org/10.1186/1754-6834-5-10

Ragauskas AJ et al (2006) The path forward for biofuels and biomaterials. Science 311:484-489. https://doi.org/10. 1126/science.1114736

Rasid OA, Masura SS, Hanin AN, Masli DIA, Bohari B, Masani MYA, Parveez GKA (2020) Oil palm transgenic research: Challenges, update, and future outlook. In: Ithnin M, Kushairi A (eds) The oil palm genome. Springer International Publishing, Cham, pp 69-81

Ren C, Guo Y, Kong J, Lecourieux F, Dai Z, Li S, Liang Z (2020) Knockout of $V v C C D 8$ gene in grapevine affects shoot branching. BMC Plant Biol 20:47. https://doi.org/10.1186/s12870020-2263-3

Ricci A et al (2020) Genetic transformation in peach (Prunus persica L.): challenges and ways forward. Plants 9:971

Rihani KAL, Jacobsen H-J, Hofmann T, Schwab W, Hassan F (2017) Metabolic engineering of apple by overexpression of the MdMyb10 gene. J Genet Eng Biotechnol 15:263-273. https:// doi.org/10.1016/j.jgeb.2017.01.001

Rodríguez A et al (2018) Engineering D-limonene synthase downregulation in orange fruit induces resistance against the fungus Phyllosticta citricarpa through enhanced accumulation of monoterpene alcohols and activation of defence. Mol Plant Pathol 19:2077-2093. https://doi.org/10.1111/mpp. 12681
Rühmann S, Treutter D, Fritsche S, Briviba K, Szankowski I (2006) Piceid (resveratrol glucoside) synthesis in stilbene synthase transgenic apple fruit. J Agric Food Chem 54:4633-4640. https://doi.org/10.1021/jf060249l

Sade N, del Mar R-W, Umnajkitikorn K, Blumwald E (2018) Stressinduced senescence and plant tolerance to abiotic stress. J Exp Bot 69:845-853. https://doi.org/10.1093/jxb/erx235

Sandhya D, Jogam P, Allini VR, Abbagani S, Alok A (2020) The present and potential future methods for delivering CRISPR/ Cas9 components in plants. J Genet Eng Biotechnol 18:25. https://doi.org/10.1186/s43141-020-00036-8

Seppänen SK, Syrjälä L, von Weissenberg K, Teeri TH, Paajanen L, Pappinen A (2004) Antifungal activity of stilbenes in in vitro bioassays and in transgenic Populus expressing a gene encoding pinosylvin synthase. Plant Cell Rep 22:584-593. https://doi.org/10.1007/s00299-003-0728-0

Shires ME, Florez SL, Lai TS, Curtis WR (2017) Inducible somatic embryogenesis in Theobroma cacao achieved using the DEXactivatable transcription factor-glucocorticoid receptor fusion. Biotechnol Lett 39:1747-1755. https://doi.org/10. 1007/s10529-017-2404-4

Spokevicius AV, Van Beveren K, Leitch MA, Bossinger G (2005) Agrobacterium-mediated in vitro transformation of woodproducing stem segments in eucalypts. Plant Cell Rep 23:617-624. https://doi.org/10.1007/s00299-004-0856-1

Srinivasan C, Dardick C, Callahan A, Scorza R (2012) Plum (Prunus domestica) trees transformed with poplar FT1 result in altered architecture, dormancy requirement, and continuous flowering. PLoS ONE 7:e40715. https://doi.org/10.1371/ journal.pone.0040715

Stettler R, Bradshaw H, Heilman PE, Hinckley T (1996) Biology of populus and its implications for management and conservation. NRC Research Press, National Research Council of Canada, Ottawa

Sykes RW et al (2015) Down-regulation of p-coumaroyl quinate/ shikimate $3^{\prime}$-hydroxylase $\left(\mathrm{C}^{\prime} \mathrm{H}\right)$ and cinnamate 4-hydroxylase $(\mathrm{C} 4 \mathrm{H})$ genes in the lignin biosynthetic pathway of Eucalyptus urophylla $\times$ E. grandis leads to improved sugar release. Biotechnol Biofuels 8:128. https://doi.org/10.1186/ s13068-015-0316-x

Szankowski I, Briviba K, Fleschhut J, Schönherr J, Jacobsen HJ, Kiesecker H (2003) Transformation of apple (Malus domestica Borkh.) with the stilbene synthase gene from grapevine (Vitis vinifera L.) and a PGIP gene from kiwi (Actinidia deliciosa). Plant Cell Rep 22:141-149. https://doi.org/10. 1007/s00299-003-0668-8

Tang W, Newton RJ, Weidner DA (2007) Genetic transformation and gene silencing mediated by multiple copies of a transgene in eastern white pine. J Exp Bot 58:545-554. https:// doi.org/10.1093/jxb/erl228

Tepfer D (1990) Genetic transformation using Agrobacterium Rhizogenes. Physiol Plant 79:140-146

Thistlethwaite FR et al (2020) Linkage disequilibrium vs. pedigree: genomic selection prediction accuracy in conifer species. PLoS ONE 15:e0232201. https://doi.org/10.1371/ journal.pone.0232201

Tournier V et al (2003) An efficient procedure to stably introduce genes into an economically important pulp tree (Eucalyptus grandis x Eucalyptus urophylla). Transgenic Res 12:403-411. https://doi.org/10.1023/a:1024217910354

Trantas E, Navakoudis E, Pavlidis T, Nikou T, Halabalaki M, Skaltsounis L, Ververidis F (2019) Dual pathway for metabolic engineering of Escherichia coli to produce the highly valuable hydroxytyrosol. PLoS ONE 14:e0212243. https://doi.org/10.1371/journal.pone.0212243 
Tuskan GA et al (2018) Hardwood tree genomics: unlocking woody plant biology. Front Plant Sci 9:1799. https://doi.org/ 10.3389/fpls.2018.01799

Ullah C, Unsicker S, Fellenberg C, Constabel C, Schmidt A, Gershenzon J, Hammerbacher A (2017) Flavan-3-ols are an effective chemical defense against rust infection. Plant Physiol 175:1560-1578. https://doi.org/10.1104/pp.17.00842

Underhill AN, Hirsch CD, Clark MD (2020) Evaluating and mapping grape color using image-based phenotyping. Plant Phenomics 2020:8086309. https://doi.org/10.34133/2020/ 8086309

Van Acker R et al (2014) Improved saccharification and ethanol yield from field-grown transgenic poplar deficient in cinnamoyl-CoA reductase. Proc Natl Acad Sci USA 111:845-850. https://doi.org/10.1073/pnas.1321673111

Van Doorsselaere J et al (1995) A novel lignin in poplar trees with a reduced caffeic acid/5-hydroxyferulic acid $O$-methyltransferase activity. Plant J 8:855-864. https://doi.org/10.1046/j. 1365-313X.1995.8060855.X

Viana AP, Resende MDV, Riaz S, Walker MA (2016) Genome selection in fruit breeding: application to table grapes. Sci Agric 73:142-149

Viana AP, de Lima E, Silva FH, Glória LS, Ribeiro RM, Krause W, Boechat MSB (2017) Implementing genomic selection in sour passion fruit population. Euphytica 213:228. https://doi.org/ 10.1007/s10681-017-2020-3

Voelker SL, Lachenbruch B, Meinzer FC, Strauss SH (2011) Reduced wood stiffness and strength, and altered stem form, in young antisense 4CL transgenic poplars with reduced lignin contents. New Phytol 189:1096-1109. https://doi.org/ 10.1111/j.1469-8137.2010.03572.x

Wagner A et al (2007) Exploring lignification in conifers by silencing hydroxycinnamoyl-CoA:shikimate hydroxycinnamoyltransferase in Pinus radiata. Proc Natl Acad Sci USA 104:11856-11861. https://doi.org/10.1073/pnas. 0701428104

Wagner A et al (2009) Suppression of 4-coumarate-CoA ligase in the coniferous gymnosperm Pinus radiata. Plant Physiol 149:370-383. https://doi.org/10.1104/pp.108.125765

Wagner A et al (2011) CCoAOMT suppression modifies lignin composition in Pinus radiata. Plant J 67:119-129. https://doi. org/10.1111/j.1365-313X.2011.04580.x

Wang L et al (2017) The transcription factor MYB115 contributes to the regulation of proanthocyanidin biosynthesis and enhances fungal resistance in poplar. New Phytol 215:351-367. https://doi.org/10.1111/nph.14569

Wang JP et al (2018a) Improving wood properties for wood utilization through multi-omics integration in lignin biosynthesis. Nat Commun 9:1579. https://doi.org/10.1038/ s41467-018-03863-z

Wang X et al (2018b) CRISPR/Cas9-mediated efficient targeted mutagenesis in grape in the first generation. Plant Biotechnol J 16:844-855. https://doi.org/10.1111/pbi.12832

Watson A et al (2018) Speed breeding is a powerful tool to accelerate crop research and breeding. Nat Plants 4:23-29. https://doi.org/10.1038/s41477-017-0083-8

Wen XP et al (2008) Over-expression of the apple spermidine synthase gene in pear confers multiple abiotic stress tolerance by altering polyamine titers. Transgenic Res 17:251-263. https://doi.org/10.1007/s11248-007-9098-7
Wenck AR, Quinn M, Whetten RW, Pullman G, Sederoff R (1999) High-efficiency Agrobacterium-mediated transformation of Norway spruce (Picea abies) and loblolly pine (Pinus taeda). Plant Mol Biol 39:407-416. https://doi.org/10.1023/A: 1006126609534

Werner CR et al (2018) Effective genomic selection in a narrowgenepool crop with low-density markers: Asian rapeseed as an example Plant. Genome 11:170084. https://doi.org/10. 3835/plantgenome2017.09.0084

Wilson JP, Montañez IP, White JD, DiMichele WA, McElwain JC, Poulsen CJ, Hren MT (2017) Dynamic Carboniferous tropical forests: new views of plant function and potential for physiological forcing of climate. New Phytol 215:1333-1353. https://doi.org/10.1111/nph.14700

Wu C, Niu Z, Tang Q Huang W (2008) Estimating chlorophyll content from hyperspectral vegetation indices: modeling and validation. Agric for Meteorol 148:1230-1241. https://doi. org/10.1016/j.agrformet.2008.03.005

Yarra R, Jin L, Zhao Z, Cao H (2019) Progress in tissue culture and genetic transformation of oil palm: an overview. Int J Mol Sci 20:5353

Yoshida K, Ma D, Constabel CP (2015) The MYB182 protein downregulates proanthocyanidin and anthocyanin biosynthesis in poplar by repressing both structural and regulatory flavonoid genes. Plant Physiol 167:693-710. https://doi.org/10.1104/ pp.114.253674

Yu W, Yau Y-Y, Birchler JA (2016) Plant artificial chromosome technology and its potential application in genetic engineering. Plant Biotechnol J 14:1175-1182. https://doi.org/10. 1111/pbi.12466

Yu D, Wildhagen H, Tylewicz S, Miskolczi PC, Bhalerao RP, Polle A (2019) Abscisic acid signalling mediates biomass trade-off and allocation in poplar. New Phytol 223:1192-1203. https://doi.org/10.1111/nph.15878

Yuan L et al (2012) Molecular cloning and characterization of PtrLAR3, a gene encoding leucoanthocyanidin reductase from Populus trichocarpa, and its constitutive expression enhances fungal resistance in transgenic plants. J Exp Bot 63:2513-2524. https://doi.org/10.1093/jxb/err425

Zhang X, Misra A, Nargund S, Coleman GD, Sriram G (2018) Concurrent isotope-assisted metabolic flux analysis and transcriptome profiling reveal responses of poplar cells to altered nitrogen and carbon supply. Plant J 93:472-488. https://doi.org/10.1111/tpj.13792

Zhang Y, Chen Q, Liu MY, Ruan JY, Yu HY, Li J, Wang T (2019) Effects of benzophenones from mango leaves on lipid metabolism. Chem Pharm Bull (tokyo) 67:634-639. https:// doi.org/10.1248/cpb.c18-00905

Zhang Y et al (2020) DNA methylation and its effects on gene expression during primary to secondary growth in poplar stems. BMC Genomics 21:498. https://doi.org/10.1186/ s12864-020-06902-6

Zhu YJ, Agbayani R, Jackson MC, Tang CS, Moore PH (2004) Expression of the grapevine stilbene synthase gene VST1 in papaya provides increased resistance against diseases caused by Phytophthora palmivora. Planta 220:241-250. https://doi. org/10.1007/s00425-004-1343-1

Zuo J, Niu QW, Frugis G, Chua NH (2002) The WUSCHEL gene promotes vegetative-to-embryonic transition in Arabidopsis. Plant J 30:349-359. https://doi.org/10.1046/j.1365-313x. 2002.01289.x 